\title{
A Proper Way to Install Trapezoidal Flumes for Measurements in Furrow Irrigation Systems
}

\author{
Mohammad Shayannejad ${ }^{1}$, Saeid Eslamian², Amir Gandomkar ${ }^{3}$ \\ Maryam Marani-Barzani ${ }^{4}$, Mahboubeh Amoushahi-Khouzani ${ }^{5}$, Zahra Majidifar ${ }^{6}$, \\ Foroozan Rajaei-Rizi ${ }^{7}$, Masoud Kazemi ${ }^{8}$, Vijay P. Singh ${ }^{9}$, Shahide Dehghan ${ }^{10}$ \\ Hamid-Reza Shirvani-Dastgerdi $^{11}$, Hossein Norouzi ${ }^{12}$, Kaveh Ostad-Ali-Askari ${ }^{13 *}$ \\ ${ }^{1,2}$ Department of Water Engineering,Isfahan University of Technology, Isfahan, Iran. \\ ${ }^{3,10}$ Department of Geography, Najafabad Branch, Islamic Azad Universiry, Najfabad8514143131, Iran \\ ${ }^{4}$ Department of Geography, University of Malaya (UM), 50603 Kuala Lumpur, Malaysia. \\ ${ }^{5}$ Water Engineering Department, Science and Research Branch,Islamic Azad University, Tehran, Iran. \\ ${ }^{6}$ Department of Agronomy and Plant Breeding, Lorestan University, Lorestan, Iran. \\ ${ }^{7}$ Water Engineering Department,Shahrekord University, Shahrekord, Iran. \\ ${ }^{8}$ Civil Engineering Department, Najafabad Branch,Islamic Azad University, Iran. \\ ${ }^{9}$ Department of Biological and Agricultural Engineering \& Zachry Department of Civil Engineering, \\ Texas A and M University, 321 Scoates Hall, 2117 TAMU, College Station, Texas, U.S.A. \\ ${ }^{11,13}$ Department of Civil Engineering, Isfahan (Khorasgan) Branch,Islamic Azad University, Isfahan, \\ Iran. \\ ${ }^{12}$ Faculty of Civil Engineering, Maybod Branch,Islamic Azad University, Maybod, Yazd, Iran. \\ *Corresponding Author: Kaveh Ostad-Ali-Askari, Faculty Member, Department of Civil Engineering, \\ Isfahan (Khorasgan) Branch, Islamic Azad University Blvd, Arqavanieh, Jey Street, P.O.Box: 81595-158, \\ Isfahan, Iran, Email: kaveh.oaa2000@gmail.com.
}

\begin{abstract}
Accurate measurements of hydraulic characteristics of flow are needed for design and evaluation of irrigation systems. For measuring flow, flumes are commonly used. is in order to obtain accurate readings for flow measurement, flumes should not be submerged and the upstream flow should not be affected by the downstream flow. This study investigates a proper way to install trapezoidal flumes that can be applied in many ways to measure in flow and outflow discharge in furrow irrigation systems. During sixty field operations, it was discovered that the flume has to be installed at least four centimeters above the bottom of furrow, in addition to the alignment on each side. This is essential for proper functioning of the flume under the conditions of free flow., Measurements made showed that if flume was held four centimeters above the bottom, the percentage of submergence in different depths of water, had met the standard rate (lower than 70\% submergence), and hence the percentage of the error in flow measurement was reduced. In order to ensure the free flow in the trapezoidal flume, the large number of field operations showed that the entrance of the flume, which is used to analyze the inflow, has to be installed at a height of four centimeters or more above the bottom of furrow, with the condition that its entrance borders are strengthened. The exit of the flume should also be firmly fixed on the bottom of furrow in order not to impede the passage of flow, with the condition that beneath the flume the furrow bottom should be made deeper in order to create free flow. These recommendations are important, especially in furrow irrigation systems.
\end{abstract}

Keywords: Furrow Irrigation, Trapezoidal Flume, Flow Intensity, Submergence Percentage.

\section{INTRODUCTION}

Measurement of flow discharge is important for design and evaluation of irrigation systems [1]. Flumes are commonly employed for discharge measurement instruments. They have a form of an open channel having a special shape and a constricted-throat section. The material that flumes are made up of can be concrete, metal, or fiberglass. Flumes of standard designs are available that allow to measure a wide range of flows. Two commonly used types of flumes are Parshall flumes and trapezoidal flumes. Flumes are used in low and steady streams, they require a relatively small head loss, and do not require upstream reservoirs to reduce the approach velocity. Flumes are self-cleaning and can operate accurately over a wide range of flows. As water approaches the flume, the velocity of 
flow has little effect upon the flume operation, unless the flume is being submerged (water backing up in the throat). In order to obtain accurate measurements of flow by the flume, it is enough to measure only one head (if the flow is free in the flume). A pre-built flume can easily be used in cold regions where frost might occur during winter. The cost of a flume that is cast in place is relatively high. In order to get a correct and right form of a flume, it is necessary to pay attention to its dimensions, such as throat width, convergence and divergence sections, slope sidewalls, and correct form of staff gauge to measure flow depth $[2,3]$.

\section{a) Parshall Flume}

This type of flume was developed at the end of 1920 for water flow measurement. The flume permanently or temporarily installed is also used to measure wastewater flow $[4,5]$. The advantages of Parshall flume include: (1) Because of its special shape, sediment particles are usually removed from it and as a result the possibility of errors in flow discharge measurement is minimized; and (2) The head loss in a Parshall flume is $25 \%$ smaller than in a weir [6].

\section{b) Trapezoidal Flume}

The trapezoidal flume is relatively new, accurate and has advantages like Parshall flume, and its construction is simpler. The trapezoidal flume with zero throat width (triangular section) is used to measure low flows, such as in furrow irrigation [7]. The trapezoidal flume cross section corresponds to the shape of many farm ditches. Because its sides diverge with depth, the trapezoidal flume of a given throat width can carry a wider range of flows than can the same size Parshall flume. This type of flume can be used at a higher degree of submergence (un free water flow) than the Parshall flume (up to $80 \%$ ), and it can measure flow discharge with an error of less than $3 \%$ before a correction factor is used [8].

The trapezoidal flume is installed in the same manner as is the Parshall flume and it should be installed level in both directions as much as possible. It is also possible to install it on slopes, as it is done within concrete ditches and within determined and fixed limits, that the maximum slope limit for proper installation is about 0.0035 meter per meter or the critical slope for the given flow. If the place of installment is sloping, the zero reference on the staff gauge should be the same as the elevation of the center of the throat section. This means that the zero reference on the staff gauge if the bottom is a slope is not zero anymore, but it shows the height difference between the throat bottom and the entrance section bottom [9, 10]. The staff gauge can be attached to the sloping side wall of the trapezoidal flume. In this case the flume should be carefully leveled transversely so the staff gauge is on the exact slope specified, but the use of a stilly well is more accurate. If the slope is suitable, the bottom of the flume and the bottom of a lined channel can be the same [11-15]. If the slope is not suitable, which is usually the case, the flume entrance opening will be above the channel bed level. It must be kept in mind that the flume's entrance must always be above the channel bed, and its height must be selected to provide free flow. The height is being selected in the same manner as that used for the Parshall flume, in a way that submergence is $70 \%$ or lower (in order to provide free flow). In Figure 1, a correction factor for different positions of submergence of the trapezoidal flume is shown. The discharge measurement of h1 under free flow conditions at the flume's entrance should be read. If the ratio of submergence is $80 \%$ or more then the correction factor shown in Figure 1 should be used [16-18].

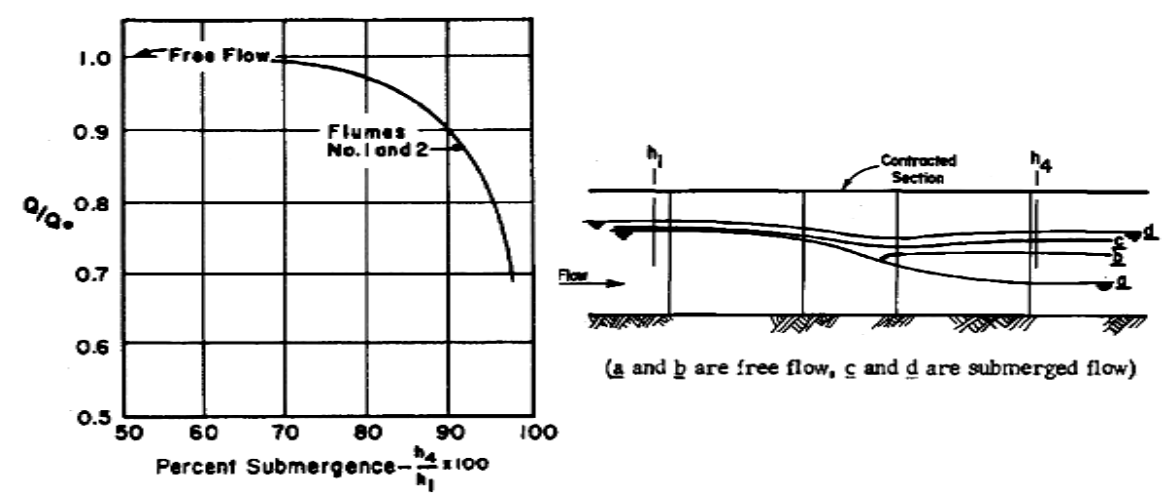

Figure1. Discharge correction factor for different positions of the trapezoidal flume submergence. To note: $Q-$ actual discharge; $Q_{o}-$ observed discharge; $h_{4}$ - depth of water at the flume's exit. 
It should be noted that the primary equation for the flow in the flumes results from the energy equation and continuity equation [19].In the present research a proper way to install trapezoidal flumes applicable under non-submerged conditions in the furrow irrigation systems is investigated.

\section{MATERial AND MethodS}

In order to achieve the objective of this study, 60 furrow irrigations under the conditions of free flow in the trapezoidal flume type 2 WSC were analyzed. Field operations were conducted in the furrows on the farm of the Isfahan University of Technology. Different positions for the installment of the trapezoidal flume were tested in order to provide free flow at the beginning and at the end of furrows. The length, width, and depth of these furrows were, respectively, 42 meters, 60 centimeters, and 20 centimeters, discharge was 0.8 liters per second, slope was $0.1 \%$ degree, and flow depth was approximately 8 centimeters. The flume was set in a way to prevent leakage around it and was installed level on every side [20].

\section{RESULTS AND DISCUSSION}

From field operations, it was observed that the flume should be installed at least four centimeters above the bottom of furrow in order to operate under free flow condition, because under this condition standard submergence percentage ( $70 \%$ or less) was being achieved which resulted in the reduced possibility of error in discharge measurement. After many irrigations, $t$ was found that in order to secure free flow in the trapezoidal flume, the flume entrance should be set at a height of four centimeters or more and the sides of the furrow should be strengthened and made higher before setting the flume in order to prevent head loss [21]. Also, in order to prevent water retention behind the flume's exit in the furrow and to prevent errors in the input and output calculations and in the calculations related to infiltration, the installment place for the flume was determined to be the channel bed with the condition that a few meters before the flume's exit should be made deeper to provide the free flow in the flume (Figure 2).
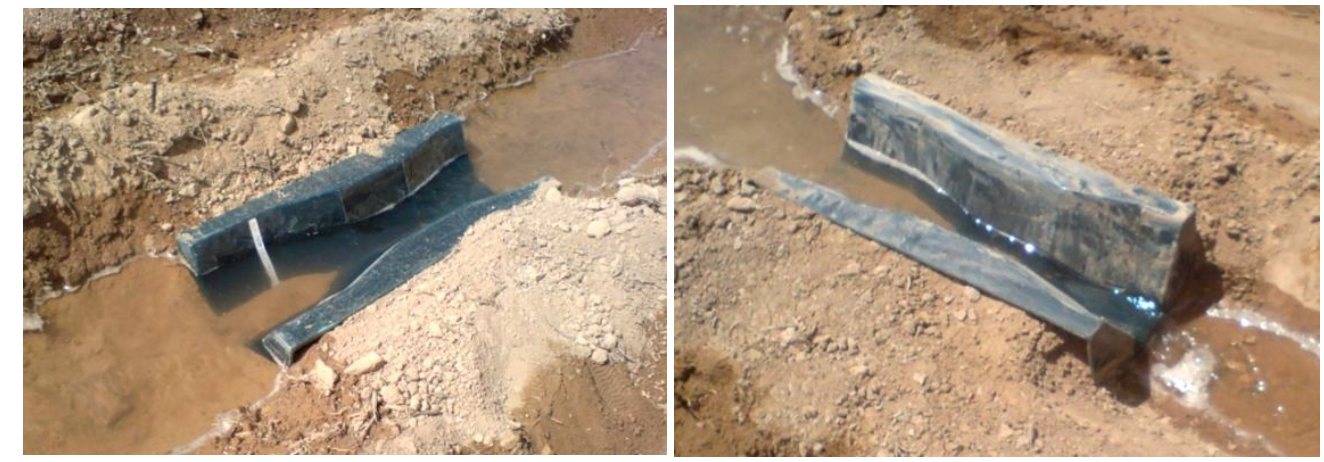

Figure2. Providing free flow and submerged flow (right and left accordingly) when following the proper way of installation of the trapezoidal flume and when not following it.

\section{CONCLUSIONS AND RECOMMENDATIONS}

In order to increase the accuracy of flow measurement in furrow irrigation systems by the trapezoidal flume and taking into account the conditions of farm irrigation furrows [where discharge was approximately 0.8 liters per second (approximately eight centimeters water depth in the furrow) and slope was $0.1 \%$ degree], it was necessary for the flume to be installed at least four centimeters above the furrow bed to provide inflow (with the condition that the entrance sidewalls were strengthened). At the exit section the flume should be installed on the furrow bed not to impede flow and at the same time it was necessary to provide such conditions (proper drainage) so that the background rejection and water backing did not occur [22].

\section{REFERENCES}

[1] Lima IBT. (2005) Bio geo chemical distinction of methane releases from two Amazon. Hydro reservoirs. Chemosphere; 59: 1697-702.

[2] Eslamian, S. S., Shah Mansuri, M. R., Farid, F., (2010) Cognition Phase Studies of the Ab-terkiBazoft Rivers hydroelectric power plant, Volume III, pp. 117. 
[3] Ostad-Ali-Askari, K., Shayannejad, M. 2015, Study of sensitivity of Autumnal wheat to under irrigation in Shahrekord, Shahrekord City, Iran. International Journal of Agriculture and Crop Sciences, 8 (4), 602-605.

[4] Shayannejad, M., Akbari, N., Ostad-Ali-Askari, K. 2015, Study of modifications of the river physical specifications on muskingum coefficients, through employment of genetic algorithm. International Journal of Development Research, 5(3), 3782-3785.

[5] Ostad-Ali-Askari, K., Shayannejad, M. 2015, The Reviews of Einstein's Equation of Logarithmic Distribution Platform and the Process of Changes in the Speed Range of the Karkheh River, Khuzestan province, Iran. International Journal of Development Research, 5(3), 3786-3790.

[6] Ostad-Ali-Askari, K., Shayannejad, M., Ghorbanizadee-Kharazi, H. 2015, Assessment of artificial neural network performance and exponential regression in prediction of effective rainfall, International Journal of Development Research, 5(3), 3791-3794.

[7] Shayannejad, M. Akbari, N. and Ostad-Ali-Askari, K. 2015, Determination of the nonlinear Muskingum model coefficients using genetic algorithm and numerical solution of the continuity. Int. J. of Science: Basic and Applied Research, 21(1), 1-14.

[8] Ostad-Ali-Askari, K., Shayannejad, M. 2015, The Study of Mixture Design for Foam Bitumen and the Polymeric and Oil Materials Function in Loose Soils Consolidation. Journal of Civil Engineering Research, 5(2), 39-44. DOI: 10.5923/j.jce.20150502.04

[9] Sayedipour, M., Ostad-Ali-Askari, K., Shayannejad, M. 2015, Recovery of Run off of the Sewage Refinery, a Factor for Balancing the Isfahan-Borkhar Plain Water Table in Drought Crisis Situation in Isfahan Province-Iran. American Journal of Environmental Engineering, 5(2): 43-46. DOI: $10.5923 /$ j.ajee.20150502.02

[10] Ostad-Ali-Askari, K., Shayannejad, M. 2015, Developing an Optimal Design Model of Furrow Irrigation Based on the Minimum Cost and Maximum Irrigation Efficiency. International Bulletin of Water Resources \& Development, 3(2), 18-23.

[11] Ostad-Ali-Askari K. Groundwater. Horouf chin publisher, First Edition, 2015. ISBN: 978-6007419-33-5.

[12] Shayannejad M, Ostad-Ali-Askari K. Modeling of solute movement in groundwater. Kankash publisher. First edition, 2015. ISBN: 978-600-136-256-9.

[13] Shayannejad M, Ostad-Ali-Askari K. Optimization and its application in water resources management. Kankash publisher. First edition, 2015. ISBN: 978-600-136-248-4.

[14] Ostad-Ali-Askari K. Nitrate pollution in groundwater. Horoufchin publisher, First Edition, 2015. ISBN: 978-600-7419-23-6.

[15] Ostad-Ali-Askari, K., Shayannejad, M. 2015, Presenting a Mathematical Model for Estimating the Deep Percolation Due to Irrigation. International Journal of Hydraulic Engineering, 4(1), 17 21. DOI: 10.5923/j.ijhe.20150401.03.

[16] Ostad-Ali-Askari, K., Shayannejad, M. 2015, Usage of rock fill dams in the HEC-RAS software for the purpose of controlling floods. American Journal of Fluid Dynamics, 5(1), 23-29. DOI: 10.5923/j.ajfd.20150501.03.

[17] Raeisi-Vanani, H., Soltani Todeshki, A. R., Ostad-Ali- Askari, K., Shayannejad, M. 2015, The effect of heterogeneity due to inappropriate tillage on water advance and recession in furrow irrigation. Journal of Agricultural Science, 7(6), 127-136.

[18] Soltani-Todeshki, A. R., Raeisi-Vanani, H., Shayannejad, M., Ostad-Ali-Askari, K. 2015, Effects of magnetized municipal effluent on some chemical properties of soil in furrow irrigation. International Journal of Agriculture and Crop Sciences, 8(3), 482-489.

[19] Ostad-Ali-Askari K, Shayannejad M, Golabchian M. Numerical methods in groundwater. Kankash publisher. First edition, 2015. ISBN: 978-600-136-276-7.

[20] Ostad-Ali-Askari, K., Shayannejad, M. 2015, Optimal design of pressurized irrigation laterals installed on sloping land. International Journal of Agriculture and Crop Sciences, ISSN 2227670X. 8(5), 792-797. 
[21] Ostad-Ali-Askari K, Shayannejad M, Eslamian S, Jahangiri A.K, Shabani A.H, Environmental Hydraulics of Open Channel Flow S. Kankash publisher. First edition, 2015. ISBN: 978-600136-303-0.

[22] Ostad-Ali-Askari K, Shayannejad M, Eslamian S, Navab-Pour B. 2016, Comparison of solution of Saint-Venant equations by characteristics and finite difference methods for unsteady flow analysing in open channel. International Journal of Hydrology Science and Technology, 6(3), 9-18.

Citation: M. Shayannejad et al. "A Proper Way to Install Trapezoidal Flumes for Measurements in Furrow Irrigation Systems", International Journal of Research Studies in Agricultural Sciences (IJRSAS), vol. 3, no. 7, p. 5, 2017, http://dx.doi.org/10.20431/2454-6224.0307001.

Copyright: (C) 2017 Authors. This is an open-access article distributed under the terms of the Creative Commons Attribution License, which permits unrestricted use, distribution, and reproduction in any medium, provided the original author and source are credited. 